\title{
ECONOMIC INSTITUTIONS OF REGULATION AND COUNTERING ABUSES IN PROPERTY RELATIONS
}

\begin{abstract}
Institutions are made up of formal rules (constitutions, laws, and regulations) and informal constraints (conventions and norms of behavior), and the way both are enforced. Wellspecified property rights that reward a productive and creative activity, a legal system that enforces such laws at low cost, and internal codes of conduct that are complementary to such formal rules are the essential underpinning to productive economy. In order to counteract the illegal property redistribution, it is necessary to have a complex system of uniform norms and interrelated standards of practice, such as legal framework, common policy in the field of law enforcement and coherent policy of economic security. In the article the system of regulation of property rights institutions in Ukraine has been analyzed and an effective option has been suggested. They were based on the economic interest more than on administrative enforcement.
\end{abstract}

Keywords: economic institutions, economic policy, macroeconomics, microeconomics, property relations.

\section{INTRODUCTION}

Existing property relations and conditions of implementation are the keys to the effective functioning of the economy and the state as a whole in the form of individual components of economic policy - institutions.

The institutions were first introduced in their present definition by Douglass North in 1990, which summarizes much of his earlier work relating to economic and institutional change. In this work, North defines institutions as "humanly devised constraints that structure political, economic and social interactions." (North, 1991). The constraints, as North describes, are devised as formal rules (constitutions, laws, property rights) and informal restraints (sanctions, taboos, customs, traditions, code of conduct), which usually contribute to the perpetuation of order and safety within a market or society.

Institutions, in today's meaning, are the collection of specially created economic, legal, legislation and regulations that act as a constraint to economic agents, as well as control mechanisms for their implementation and protection.

Institutions are created by human beings and make sense as a continuous response to different levels of uncertainty. Despite the fact that the fundamental reason for creating the institutions associated with people trying to structure the environment to make it more predictable, appropriate efforts can and do lead to an increase in uncertainty. For example,

1 Nataliia Gerasymchuk, PhD, Associate professor of Department of Economics, Rzeszow University of Technology; e-mail: n.gerasymchu@prz.edu.pl. ORCID: 0000-0002-3931-5320. 
the development of formal property rights has made the overall social environment more predictable, but increased uncertainty for those who have traditionally used the no man's land, not having specific rights to it.

Taken together, the institutions organize the influence on economic processes and relationships, structure interaction of the participants, make the incentives work. The essential role that institutions play in society is to reduce uncertainty in the economic relations by establishing a stable structure of interactions between the economic agents.

Therefore, the development of economic policy institutes, bound by numerous bonds depends primarily on the stable and sound development of the economy and property.

The main task of this article is to analyze system regulation of property rights institutions in Ukraine and to offer an effective option, based on the economic interest more than administrative enforcement.

\section{LITERATURE OVERVIEW}

Topics of property relations are traditionally studied by scientists in the sphere of law, economic policy - by economists, processes in society transformation - by sociologists. About economic institution formation as the prerequisite to the formation of state first was mentioned by Hodgson, G. M. in his work Economics and Institutions: A Manifesto for a Modern Institutional Economics (Hodgson, 1989). This narrative was caught up by North Douglass C. in "Institutions, Institutional Change and Economic Performance" (North, 1990) and since then those authors are considered as founders of institutions theory.

Of course, before those terms were mentioned in economic literature, there were tons of work on theory of state and law. But as it often happens, another point of view, this time from economic perspective - showed a totally new meaning of this topic.

In Ukrainian scientific literature the main authors who dedicated their work to the topic of economic institutions are Malik Mykola Yosypovych, Shpikuliak Oleh Grygorovych (Malik, Shpikuliak, 2010), Stepanenko S. V. (2008).

A lot of questions of correct establishment of economic relations were covered by the works of Arefieva O. V. (Arefieva, Vovk, Posypaiko, 2020), Nitsenko V. (Nitsenko, 2020) and many others.

Fiscal institutions and audit systems were studied in detail by many researches, the closest to the topic is the works of Vasurenko L. V., Kuksa I. N., Shtuler I. (2019), Lisovyi Andryi (2018), Titenko Zoya (2017) and a lot of others.

Despite the fact that this topic was studied and almost anything about it was discussed (for example, in Development of agricultural entrepreneurship: trends and prospects, 2012), nowadays, due to another global change in all spheres of economic and social life, this topic is still up-to-date. As the reality shows, lessons were not learned, and Ukraine seemed to have returned to initial stage of institutional development. Thus, the topic of economic institutions of regulation and countering abuses in property relations is actual in new circumstances, and the author hopes that this time it would be successful.

\section{RESULTS AND DISCUSSION}

In the present circumstances, the economic institutions have a deterrent effect, often leading to critical situations in the area of ownership. This requires more detailed consideration of the impact of economic policy, as a set of economic measures and actions aimed at achieving clearly defined results, including institutional, competition, monetary, 
fiscal, financial, foreign trade, investment and pricing policies to ensure the economic security of the property.

The importance of the state's economic policy is focusing on the institutional changes, which include a number of components to improve: property relations, promoting the transition to modern enterprise business organization, competition between market participants.

Institutional policy involves formation corresponding to market principles of the legal and institutional environment, a general statement for all businesses procedures and rules of conduct. Performing of institutional policies are including reform of enterprises in accordance with the modern structure of the economy and development of the full support of small business, competitive formation of large corporate entities, providing incentives for the transfer of state property into private property or on the contrary, the legislative creation and support of new market institutions.

An arsenal of institutional policy consists of tools such as: providing a legal basis of market processes, the development of the legal bases for creation, operation and liquidation of enterprises, including through bankruptcy, establishing effective organizational and economic structures, the transformation of property relations.

Development of market relations and property relations, which began in the 90s, was accompanied by delay in the creation and formation of the institutional framework. This contradiction in the real market relations and in the development of institutions is preserved in the present. The positive result of the reform of the entire system of economic relations has been the stabilization of the economy, creating a constitutional framework to ensure and protect the interests, rights and freedoms of the individual, society and the state. However, despite the fact that the problem of economic growth has been resolved, we cannot solve the problem of incentives and motivation to ensure the stability of property relations between the state and business. Neither the state nor business are ready today to go to the classical models of the functioning of the rule of law and competitive market economy, to act strictly within the legal framework. Transformation policy of 90s is seemed to be unsuccessful and, above all, have poor institutional impact on economic policy at this time (Lisovyi at al., 2018). Instead of the normal and aimed at stabilizing development and sustainability of government regulation, nowadays model of governance is archaic. Economic transition and the transition period for the property relations is to be completed (Malik, Shpikuliak, 2010). Formally, the transition took place, relationships were formed, but these relationships are unstable, accompanied by a constant transfer of property from hand to hand, bypassing the objective of market mechanisms, with corruption and bureaucratic levering by criminal pressure and terror. This incompleteness of the transition of ownership preserves the legitimacy of ownership. Since it has not ended, then the property will inevitably be played in various forms, including through processing. In addition, there are no effective and efficient government institutions, including the state property management, institutional policies and continuing inertia of old relationships.

Public finances have a decisive impact on the real economy as a part of the budget commitments and as an incentive to increase investment activity and a reorientation of financial flows from speculative financial markets in the sphere of material production. This is the main objective of fiscal policy in the sphere of production - support real businesses, not speculators (Shpikuliak, 2008). There are visible traces of interlocking problems of fiscal policy and crisis support for businesses. 
Shaping the revenue and expenditure side of the budget, the state has an impact on the behavior of producers, the growth and use of income. Respectively, at infinity redistribution of property tax revenue shortfall is in the budget and, as a consequence, for the State to the socio-economic guarantees and obligations. But the main instrument of fiscal policy to support the economy and the protection of property rights is government subsidies and support for enterprises in various sectors of the economy, allowing the budget deficit to make up in order to prevent bankruptcy, and increase in accounts payable (World Encyclopedia of Entrepreneurship, 2011).

In this regard, in order to ensure the economic security of property in the fiscal policy mechanisms should be used in the forms of supporting businesses from the state budget and other funds (Shpikuliak, 2008). For example, state could provide necessary conditions for the establishment of public investment development banks. Then the state will not only receive part of the profits from the modernization of businesses and industries, but also create new ones, which will facilitate the expansion of the revenue-based budget. In addition, to protect property rights and to guarantee its integrity is necessary to create conditions for effective budgeting, allocation and use of budgetary funds, specifying their intended purpose (Malik, Shpikuliak, 2010).

The task of competition policy, antitrust regulation system - one of the most important in a market economy, which should focus on the control of balancing the interests of economic entities, to ensure that economic entity, which has a dominant position, did not suppress the weaker as well as a violation of property rights because of this dominant position. It is important not only to limit the monopoly and abuse of dominant position, to enforce the competition rules, to punish their violation, but also to create a fair competitive environment, which, in general, will guarantee the protection of the property rights and interests of the owners.

At the same time the main body of the government, with the commensurate authority in this field - the Antimonopoly Committee of Ukraine - has no authority to protect property rights. Although it is obvious that if the rights of the owner are protected, there will be normal competitive environment.

Today antimonopoly control tools can be schematically represented as follows (see Fig. 1).

In general, monitoring activities of the competition authority is not effective enough. It does not appeal to the line ministries for the competition policy in the industry, does not have investigative powers (Bodnarchuk, Zhuravsky, Mikhalchenko, Mikhalchenko, 2018).

Thus, competition policy is of crucial importance in countering criminal seizures. It must be radically strengthened, particularly in the area of ownership. It is crucial to decriminalize relations on the creation, distribution, redistribution, transmission from hand to hand objects of ownership, freeing it from the control of organizational monopolies. Since blocking criminal structures competition creates blood clots in the economic system, seriously hampering the transformation of property relations.

In modern conditions, the tax system is not favorable to business and push companies to hide income and move into the informal sector, since it does not solve the problem of tax incentives. Implementing the policy of reducing the tax burden on business will solve the problem of increasing tax payments to the budget. However, state failed to build civilized relations between itself and the owner, instead focusing on the system of tax exemptions on social issues. For effective implementation of macroeconomic policies must be considered challenging and distribution functions of taxes, improve tax and business climate. Collect 
taxes in a way to motivate to increase revenues is economically correct (Lisovyi, 2018). For archiving this goal is necessary to set different tax rates, adapt the procedure of tax collection and benefits, consider the impact on the development of priority sectors, support for non-competitive, but socially important sectors, monitor potential targets of raider attacks. Tax policies affect the structure and the amount of costs of enterprises, the amount of their remaining net profits and, ultimately, the value of investment in the development, upgrading and maintaining the competitiveness of the goods and hence competitiveness (Podik, 2019).

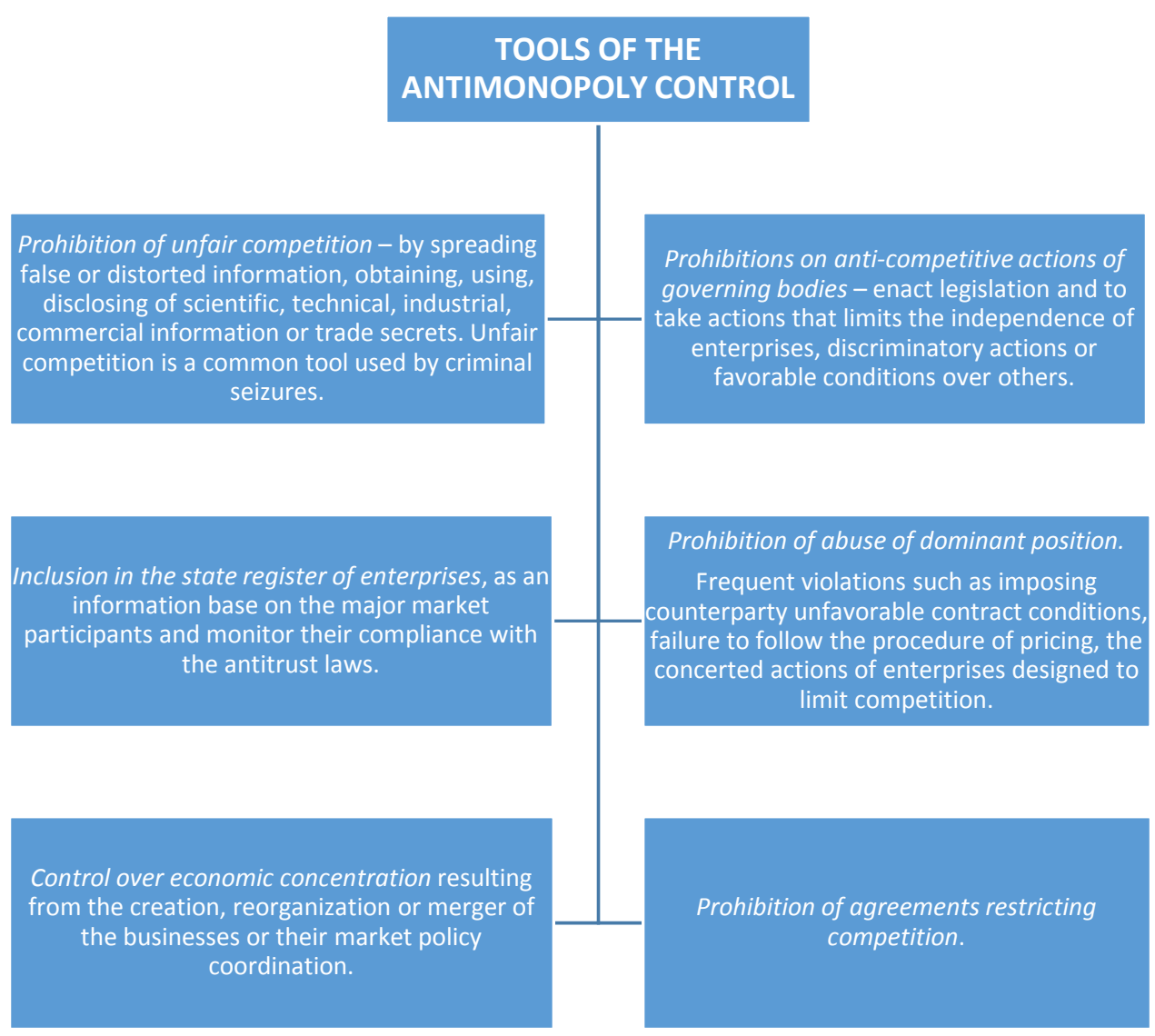

Fig. 1. Tools of the antimonopoly control

Nowadays most important financial factors which are limiting growth of the real economy, we should note the following (see Table 1).

All this makes a series of criminal redistribution of property more accessible and less expensive. Modern market economy is impossible without extensive, flexible and diverse system of credit relations, which, along with the finance help raise funds for the accelerated implementation of the expanded reproduction, accelerate economic restructuring, improve its competitiveness, dynamism of economic processes. 
Table 1. Factors limiting the growth of the real sector economy

\begin{tabular}{|l|l|}
\hline \multicolumn{1}{|c|}{ In the area of public finance } & \multicolumn{1}{|c|}{ In the area of corporate finance } \\
\hline $\begin{array}{l}\text { 1. Limited financial resources, the budget does } \\
\text { not allow to increase the amount of support } \\
\text { priority and socially important sectors of the } \\
\text { real sector. }\end{array}$ & $\begin{array}{l}\text { 1. Heavy tax burden, which reduces the } \\
\text { competitiveness of enterprises and the level of } \\
\text { economic efficiency, as much income limits at } \\
\text { the disposal of companies. }\end{array}$ \\
\hline $\begin{array}{l}\text { 2. Insufficient funding for several sections of } \\
\text { the budget in the first place, production } \\
\text { department, which leads to an increase in } \\
\text { accounts payable budget holders. }\end{array}$ & $\begin{array}{l}\text { 2. Lack of working capital in the enterprises do } \\
\text { not allow them to increase production capacity } \\
\text { and to use all the available production capacity. }\end{array}$ \\
\hline & $\begin{array}{l}\text { 3. Increase in accounts payable now poses } \\
\text { a threat to the existence of a bankruptcy or by } \\
\text { leasing their space and equipment }\end{array}$ \\
\hline & $\begin{array}{l}\text { 4. Lack of funds, resulting in barterization } \\
\text { calculations and degrades the structure of their } \\
\text { accounts receivable and payable, the economic } \\
\text { performance of production activities. }\end{array}$ \\
\hline
\end{tabular}

Source: Developed based on: (Lisovyi, 2018).

Foreign economic policy is aimed at regulating economic relations with other countries in the global marketplace. The main strategic objective of foreign policy is the creation of favorable external conditions for the expanded reproduction of the country (Antoniuk, 2019).

There is an extensive set of tools of foreign policy - an incentive for exporters, import or export restrictions, measures to attract or restrict the access of foreign investment in the economy, changes in customs duties, membership in international economic organizations, the establishment of special customs regimes and preferences. The main goal of foreign policy in ownership issues is maintenance of domestic producers in world markets and their protection in the domestic market and, above all, the protection of property and the owners of the non-economic and unlawful seizure of foreign investors.

Investment and innovation policy. Investment activity is a necessary component of effective development of any enterprise and is a prerequisite for economic growth in the country.

Private companies are finding their own source of investments, loans and borrowings. Public investment is financed by tax revenues, profits of state institutions, by issue of domestic and foreign loans. The value of investments fluctuates in time. Therefore, conducted by the state investment policy should be aimed at guaranteeing the stability of investment in the national economy.

Innovation policy as a kind of investment policy aims to ensure government regulation of the creation, operation and eventual disposition of innovations in the economy, i.e. regulates the flow of investment resources, in the development and production of technological innovations in order to maintain a progressive technology industries.

Instrumentation of investment and innovation policy is a synthesis of various tools of described above policies. It can be represented as direct government funding, legislative 
support of the investment process, government borrowing, and tax benefits, depreciation policy, the development of market institutions (stock market, venture capital funds, investment banks), promoting joint ventures with foreign partners, investment and innovation projects (Hanushchak, Shcherbak, 2016).

Tariff (price) policy is part of the economic policy, aimed at determining the prices of goods and services.

In order to achieve the strategic objectives prices, including the rental of production space, energy and utilities, transportation services, should be installed in such a way that, on the one hand, to meet the needs and requirements of customers, and the other - to promote achievement of the company goals, namely, the flow of financial resources.

In this context, the tariff policy of the state to protect the rights of property owners should now be directed to:

- modernization of the entire set of engineering equipment by funds from the budget, businesses, instead of end users, and cover the costs of enterprises regardless of ownership;

- containment of significant growth rates in energy and utility services, as the constant growth rates forced the company to release the funds that are involved in the production process;

- setting size limits with changing of utility rates.

Thus, establishing an acceptable level of tariffs, stable and predictable tariff policy allow enterprises to improve production in accordance with the priorities of modernization, contribute to its efficiency, lowering production costs (Arefieva, Vovk, Posypaiko, 2020). This allows businesses to feel confident in the market, pay more attention to the strategic goals of the company and improve its corporate governance, and most importantly - create conditions for free and fair competition, thereby protecting the rights and interests of the owners.

On the basis of the above tools and built the Government's economic policy of the country and, above all, economic policy, aimed at the protection and stability of property rights and its opposition to the criminal process stage.

Of all the tools in the selected group of the fundamental instruments in which the state is going to affect the economy in accordance with the chosen course, since the use of all the tools at once is very difficult and oppressive (Sonin, 2005). In addition, some tools are inherently contradictory.

Implementation of active economic policy, restructuring of industries and the development of depressive tech manufacturing sectors hampered by a number of objective factors that restrict the development of investment activity. The main problematic objective factors are (Nitsenko, 2020):

- narrow economic opportunities for savings, including those due to the loss of a large resource base for national savings crisis impairment of productive capital, distrust of the government and the banking system, the speculative orientation of leverage in the banking system itself, its failure to invest in the real sector the economy;

- general underdevelopment of market institutions that provide the transformation of savings into productive investments;

- Tax legislation which is not stimulating to invest funds of businesses in their capital stock because of unclear and doubling depreciation policy; 
- high rents;

- high tariff policy.

Tariffs increase the price of products and reduce incentives to improve production. Practice of increasing tariffs without prior notice does not give economical subject a chance to prepare for the new conditions and significantly increases costs. It also creates additional conditions for the crime redistribution of property.

Better conditions for innovation presented by modern state depreciation policy, which was presented in new Tax codex. The previously existed depreciation rates averaged and did not discriminate between technologies XX and XXI centuries, so it was unprofitable to buy at high prices advanced equipment, standard life which is 10 years (Arefieva, Vovk, Posypaiko, 2020). By the time the equipment is morally obsolete, but will be listed on the balance sheet. Those funds, which are released through the amortization process and are a source of investment in industrial development, due to a lack of working capital to service the manufacturing process, are often used for current consumption (according to the statistics, companies used for current consumption of at least $50 \%$ of accumulated depreciation) (State Statistic Service of Ukraine, 2020).

Thus, existing policy measures, including the measures of the privatization policy of $90 \mathrm{~s}$ and 2000s, disparities in the ratio of large, medium and small enterprises in the economy, competition policy are not focused properly on the creation of effective ownership and property rights. Also not been solved or not solved the problem fairly consistent support for small business, Tax Legislation and facilitation of tax administration. Fiscal tax function still dominates the regulator (Titenko, 2017). State, establishing a system of exemptions (taxes, prices, interest rates), directly infringes business, pushing it into the shadow of relations, where the risks and threats to the owner and his property will increase manifold, since it can not rely on the strength and protection of the law, makes conduct business in the illegal competitive, no protection, guarantees and normal reproduction of property.

Economic institutions in terms of measures of economic policy can create the conditions for a stable and effective functioning of the economy within the thresholds, including the creation of the conditions for the effective functioning of all forms of ownership and high motivation of the owner. It is crucially necessary to establish sustainable mechanisms for trust between the state, society and business, and to protect the latter from criminal and corruptive influence. Business should not be afraid to seek assistance from the state, and it, in turn, should really protect business through various measures and mechanisms, including the economic regulators, so it will be not vulnerable to crime.

Also it attracts the attention problem of development and adoption of regulatory legal acts necessary to regulate the relationship between the subjects of the market, the establishment of common rules. The absence of legislation contributes to disorganization and a significant reduction in the effectiveness and usefulness of economic reforms in Ukraine (Vasurenko, Kuksa, Shtuler, 2019).

As a result of detailed consideration of the economic mainstay of the criminal redistribution of property, we offer design of existing and addition of new institutions of the interconnected system consisting of the following institutions (Table 2). 
Table 2. Institutes of combating of economic basics of illegal property redistribution

\begin{tabular}{|c|c|}
\hline Name of the institute & Control measures \\
\hline Economic Institute & $\begin{array}{l}\text { - freedom of Competition and Entrepreneurship } \\
\text { - the creation of motives and incentives, a positive effect on the } \\
\text { mechanism of operation of the business under the honest and fair } \\
\text { competition; } \\
\text { - Balancing the interests of all businesses; } \\
\text { - Stimulation of the transition to modern enterprise business } \\
\text { organization; } \\
\text { - The development of competition between market participants; } \\
\text { - Formation of an appropriate market principles of the legal and } \\
\text { institutional environment, } \\
\text { - A general statement for all businesses procedures and rules of conduct; } \\
\text { - Development and comprehensive support to small businesses; } \\
\text { - Legislative creation and support of new market institutions; } \\
\text { - The creation of effective institutions of governance; } \\
\text { - Reorientation of the financial flows of speculative financial markets in } \\
\text { the sphere of material production; } \\
\text { - Create the conditions for effective budgeting, allocation and use of } \\
\text { budgetary funds; } \\
\text { - Reducing the tax burden on business; } \\
\text { - Streamlining of tax payments to the budget; } \\
\text { - Boosting bank lending to the production sector and the creation of } \\
\text { conditions of increasing demand for bank credit from side of the } \\
\text { structure of the real sector of the economy, regardless of the form of } \\
\text { property; } \\
\text { - Attraction or access of foreign investment in the economy; } \\
\text { - Regulation of the flow of investment resources aimed at development } \\
\text { and creation of technological innovations in order to maintain } \\
\text { advanced technological bases of industry; } \\
\text { - Containment of significant growth rates exception conditions that lead } \\
\text { to the interests and benefits of illegal activities in the area of property, } \\
\text { based on legal norms, certain rules and restrictions; }\end{array}$ \\
\hline Legal institute & $\begin{array}{l}\text { - The protection of constitutional rights and guarantees of property, } \\
\text { - Protection of the interests of citizens and legal entities; } \\
\text { - Development of regulations providing for the rights and obligations of } \\
\text { the subjects on the proper prescription and their possible behavior; } \\
\text { - Determination of liability measures (enforcement) for violations of the } \\
\text { rules and regulations; } \\
\text { - Offer ways to protect against abuse of others (civil, administrative and } \\
\text { criminal law); }\end{array}$ \\
\hline
\end{tabular}


Table 2 (cd.). Institutes of combating of economic basics of illegal property redistribution

\begin{tabular}{|c|c|}
\hline Name of the institute & Control measures \\
\hline $\begin{array}{l}\text { Law enforcement } \\
\text { Institute }\end{array}$ & $\begin{array}{l}\text { - Investigation of crimes and offenses; } \\
\text { - Determination of punishment for their crimes and offenses; } \\
\text { - Accountability for crime and delinquency; } \\
\text { - Prevention and warning, the causes and conditions criminal } \\
\text { redistribution of property: } \\
\text { - Restoration of the rights; } \\
\text { - Verification of the constitutionality and legality of regulations; } \\
\text { - Consideration of civil, criminal and administrative cases; } \\
\text { - Implementation of Public Prosecutions; } \\
\text { - Resolution of legal disputes between legal entities and individuals; } \\
\text { - Consideration of bankruptcy cases, challenging the regulations, } \\
\text { disputes between shareholders and equity society are sought for the } \\
\text { protection of property rights; } \\
\text { - Granting the right of appeal to the Court on illegal decisions; } \\
\text { - The fight against corruption; } \\
\text { - Documentation of the rights and responsibilities of owners; } \\
\text { - Services provided by physical security and protection of property } \\
\text { owners; } \\
\text { - Development and adoption of measures to protect the rights and } \\
\text { freedoms of citizens, protection of, regardless of ownership; } \\
\text { - To ensure the protection of important state objects of critical and } \\
\text { sensitive sites, property of legal and personal contracts; } \\
\text { - Assistance to enterprises, institutions and organizations regardless of } \\
\text { ownership in developing measures to ensure the safety of their } \\
\text { property. }\end{array}$ \\
\hline
\end{tabular}

Source: Developed based on: (Malik, Shpykulyak, 2010; Stepanenko, 2008).

\section{CONCLUSIONS}

Institutions must emerge, function and play the system. Its internal components must interact not only among themselves but also with the system. This will ensure the normal system of self-regulation of the economy and create conditions that will protect enterprise and fair competition. Otherwise, there will be inevitable overlapping functions, misallocation of resources, and as a result - no result.

Thus countering the economic fundamentals of the criminal redistribution of property is necessary to ensure the economic security of the country and prevent the merging of the criminal with a legitimate business. It is important to understand that, while state fighting with the criminal seizure, it also fights with economic crime, corruption, and other very serious crimes, and the criminal underground economy in general.

In order to counteract the illegal property redistribution needed complex system of uniform norms and interrelated standards of practice, there must be: the legal framework, a common policy in the field of law enforcement and coherent policy of economic security. 


\section{REFERENCES}

Antoniuk, N. A. (2019). Theoretical and Methodological Approaches to Anti-Crisis Management of the National Economy in the Context of Decentralization: a monograph. Lutsk: Eastern European National University named after Lesia Ukrainka.

Arefieva, O. V., Vovk, O. M., Posypaiko, Ye. A. (2020). Intensification of material and technical support formation of an enterprise in the conditions of neoindustrial modernization. "Economics bulletin of the National Mining University" No. 2 (70). DOI: 10.33271/ev/70.123.

Development of agricultural entrepreneurship: trends and prospects (2012). Proceedings of the Fourth International Scientific and Practical Conference of Young Scientists. Kyiv: NSC „Institute of Agrarian Economics”.

Hanushchak-Efimenko L. M., Shcherbak V. G. (2016). Innovative entrepreneurship development based on cluster organization. "Actual problems of economics" No. 11(185).

Hodgson, G. M. (1989). Economics and Institutions: A Manifesto for a Modern Institutional Economics. Philadelphia: University of Pennsylvania Press.

Lisovyi A. V. (2018). Tax regulation of development of rural territories of Ukraine: a monograph. Melnyk Publishing House.

Lisovyi, A. V., Gerasymchuk N. A., Bodnarchuk O. H. (2018). Analysis of motivation for deregulation of entrepreneurial activity as the main way to reduce administrative barriers in the economy. "Scientific bulletin of Polissia" No. 1 (13), P. 1

Malik M. Y., Shpykulyak O. G. (2010). Institutionalization of agrarian entrepreneurship: transformation and efficiency. „Economy of agro-industrial complex” No. 7.

Meyers, W. H., Demyanenko, S. I., Johnson, T. G., Zorya, S. I. (2005). Refocusing Agricultural and Rural Development Policies in Ukraine: Action Plan for the Road Ahead. Washington DC: USAID.

Nitsenko, V. (2020). Mismanagement in Ukraine. "Problems of Management in the 21st Century” No. 15(1). DOI: 10.33225/pmc/20.15.04.

North D. C. (1990). Institutions, Institutional Change and Economic Performance. Cambridge: Cambridge University Press.

Olson, M. (2000). Power and Prosperity: Outgrowing Communist and Capitalist Dictatorship. New York: Basic Books.

Shpikuliak, O. H. (2008). Institutional peculiarities of entrepreneurship and social capital development in agrarian sphere. ,Agrosvit” No. 11.

Sonin, K. (2005). Institutional theory of infinite redistribution. „Questions of economics”, No. 7.

State Statistical Service of Ukraine. Access on the internet: http://www.ukrstat.gov.ua

Stepanenko, S. V. (2008). Institutional analysis of economic systems (problems of methodology). Kyiv: KNEU.

The handbook of research on entrepreneurship in agriculture and rural development (2011). Edited by Gry Agnete Alsos, Sara Carter, Elisabet Ljunggren and Friederike Welter. Edward Elgar Publishing Limited.

Titenko, Z. M. (2017). System of electronic administration of value added tax for agricultural producers. "Economic Bulletin of the Zaporizhia State Engineering Academy” No. 2 (2).

Vasurenko, L. V., Kuksa, I. N, Shtuler, I. U. (2019). Determination of the level of state regulation of arrangements for the payment of labour by method clustering of branches of national 
economy. "Financial and credit activity: problems of theory and practice" No. 29, Vol. 2. DOI: 10.18371/fcaptp.v2i29.171901.

World Encyclopedia of Entrepreneurship (2011), Edited by Leo-Paul Dana. Edward Elgar Publishing Limited.

DOI: $10.7862 /$ rz.2021.mmr.01

The text was submitted to the editorial office: December 2020.

The text was accepted for publication: March 2021. 